\title{
The Research on Financial Risk Investment Policy to High Technology Industry
}

\author{
Fangwang $\mathrm{Li}^{1}$, Fangfang $\mathrm{Liu}^{2}$ \& Wen Wanying ${ }^{2}$ \\ ${ }^{1}$ School of Public Affairs, University of Science and Technology of China, Hefei, China \\ ${ }^{2}$ School of Management, University of Science and Technology of China, Hefei, China \\ Correspondence: Fangfang Liu, School of Management, University of Science and Technology of China, Hefei, \\ Anhui, 230026, China. Tel: 86-151-5516-0201. E-mail: 120563762@qq.com
}

\author{
Received: October 17, 2014 Accepted: April 2, 2015 Online Published: June 5, 2015 \\ doi:10.5539/ass.v11n18p25 URL: http://dx.doi.org/10.5539/ass.v11n18p25
}

This paper is sponsored by National Natural Science Foundation of China (Grant No.71073151).

\begin{abstract}
High technology industry with high risks and high profitability, it is because of these characteristics has attracted a lot of risk investment, the government as the main support of high technology industry, the integrated use of fiscal means such as tax and investment and financing to adjust the relationship between venture investors, venture capital company and venture enterprise. This paper introduces the two-period of partial equilibrium model, and analyses the question that how risk investment policy work on high technology industry with three aspects ranging from tax mechanism of risk investment behavior, mechanism of governmental risk investment policy to venture investors, to the influence of the tax policy for high technology enterprise on risk investment mechanism. And it points out that the governmental taxation type and tax base will affect the risk investors' desire and high technology enterprise cost of capital, which influence the development of the high technology industry.
\end{abstract}

Keywords: risk investment, high technology industry, mechanism

\section{Introduction}

For high technology industries, its generally involves technology process about research and development and transformation, which actually are closely related to innovation process. But innovative activities always have a very high uncertainty and risk. Generally speaking, the higher risk of high technology industry is mainly in technology research and development of high risk, the market demand of high risk and innovation's earnings of high risk (Luo, 2010).

First of all, because the innovation activity or technology research and development activities generally requires huge money and energy, but with incomprehensibility of research and development results, so as to make the innovation with higher failure rate. And regardless of success or failure, money and energy can directly take back (Chen, 1998). So for high technology industries, it is the high risk of technology research and development. That is to say, technology research and development with high risks makes more companies tend to copy and imitate other enterprise newly developed technology, and then lost the power of independent research and development. When more companies appear similar situation, it will appear the phenomenon of "waiting game". Second, the high technology industry both in products and technologies, the upgrading speed is very fast, but the development of science and technology is a long period of activity, so it is very likely to be the phenomenon that technology development is success but unsuccessful in the market. That is to say, Companies invest the money and energy, but the development of products and technology does not cater to the demand of the market Yong (Tao, 2004). Finally, because when the business developed high technology research and development, its highest expectations of earnings occupied the technology research and development of the total revenue, but the high technology industry exists obvious externalities, enterprise can only occupy the market portion of the earnings, which leads to the enterprise in innovation of high technology research and development as well as facing the risk that earnings can't compensate for research and development costs.

Therefore, when carrying out innovation decisions, the enterprise will face many aspects of risks, such as technology, market and benefit. It is hard to predict the prospects of develop high technology research and 
development. It greatly dampened the enthusiasm of enterprises to carry out technical innovation activities (Su, 2007), which may affect the development of high technology industry. Therefore, from this point of view, the government need to intervene to the development of high technology industry, using its own financial means, and risk investment policy, as one of the fiscal policy of the government support, by adjusting the way of venture capital to help the enterprise to reduce the risk of developing high technology, so that the high technology enterprises actively and safely pay attention to the technology development and promote the development of high technology industry.

\section{Tax Mechanism of Risk Investment Behavior}

Generally speaking, the high technology industry with high risk, but high risk of the potential of high returns will attract a lot of investment get in, which contains risk investment. The main body of venture investment has a lot, for example, securities companies, commercial banks, personal capital, venture funds, etc., these are risk suppliers or called venture investors. The risk investment company, its behavior is more like a kind of intermediary organizations, being a bridge to the risk of investors and capital demanders (Huang, 2009).

For a typical and complete surrender risk action, usually contains three units, these are venture investors, venture capital company and venture enterprise, Among them, the risk investors is the capital supplier that provide necessary funds to risk enterprise and benefit; And the risk enterprise is the capital buyer, accessing the funds from venture investors and used to support the development of their own; Venture capital firms, as mentioned above, playing a main role for providing cooperation as a mediation between investors and risk enterprise . Venture capital firm try to access the funds from venture investors through a variety of forms, and then in the form of equity and injected into the risk of enterprise, with the financial support, the venture enterprise can start to carry out business activities or to expand production, venture capital company exit the venture enterprise by means of equity sell or transfer when meets the appropriate opportunity, and get the payment. Out of funds again to other ventures, so as to realize the continuous investment cycle of growth. Therefore, the author thinks that, risk investment fund is different from other investment, mainly because it has the characteristics of circulation value-added.

From the above analysis we can see that the fund is actually constantly flow and circulation in the whole process of risk investment, and it is due to the transfer of funds, the venture capital process has the basis of taxation. However, the tax link, the form of tax and other issues, which leads to direct intervention and affect the venture investors, venture capital company and venture enterprise's behavior (Guo \& Ning, 2001). For high technology industry, venture capital investment activity is very active, it makes us analyze the taxation tache in the process of venture capital operation in detail. We can use the Figure 1 that shown below to describe the taxation tache in the process of risk investment in high technology industry.

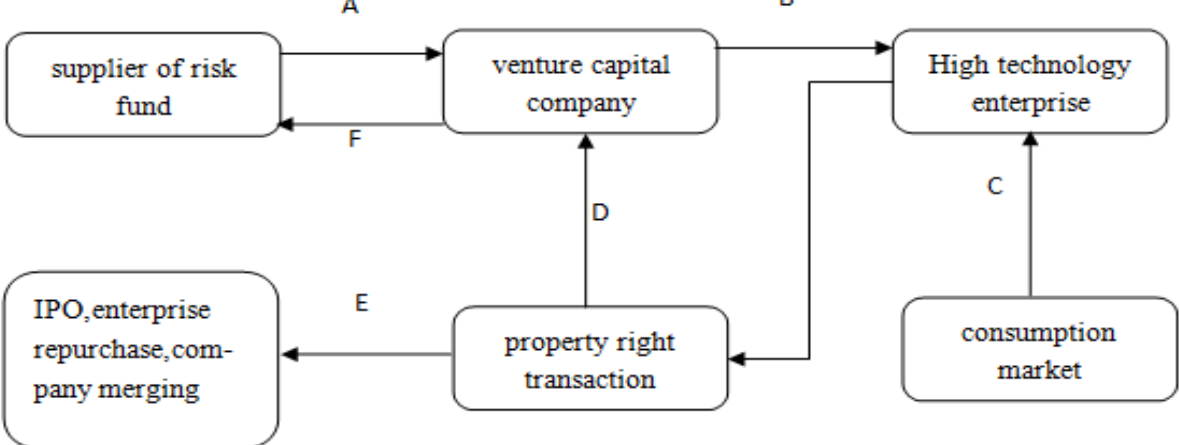

Figure 1. Tax mechanism and cash flow of risk investment behavior

From the diagram, we can see that the fund is continuously in the whole risk investment behavior of circulation, which provides the basis for the fiscal sector on taxation. The part A in the figure represents the process that risk investment companies' raises fund from the supplier of venture capital. Generally speaking, in this segment, it only involved in stamp tax and other simple taxes in the process of contract signing.

In part $\mathrm{B}$, it represents the meaning of risk investment company will be in the form of equity capital injection to the high technology enterprise, which involves the investment behavior of tax, etc. In general, for the high technology enterprises especially small and medium-sized enterprises, fiscal policy can have credit, such as direct deduction of taxable income in proportion of investment. 
In part C, high technology enterprise uses venture capital funds to carry out the operation, developed or produce products, these products for sale in the market will make high technology enterprise get the corresponding sales and profits. In this segment, the government will impose turnover tax from sales revenue according to a certain tax levy, such as value-added tax, etc. For high technology enterprise profits at the same time, the ministry of finance accounting will impose enterprise income tax, etc.

In part $\mathrm{D}$ and $\mathrm{F}$, property right transaction is completed means that risk investment funds out of the high technology enterprise, the venture capital company and the supplier of venture capital will share the investment returns in advance in accordance with the contract. If the risk investment company uses the partnership system, so in part $\mathrm{D}$ will be imposed individual income tax in accounting; if the risk investment company is in the form of corporations, so in part D, it will be imposed the enterprise income tax in accounting. To part F (supplier of risk investment risk gets investment returns), also has the similarity with part $\mathrm{D}$, that is to say, if it is the institutional investor, enterprise income taxes on its earnings is needed; If individual investors, individual income tax should be imposed.

Part E is the process about Venture Capital Company withdraws the funds, may be through the IPO, company repurchase or a variety of ways, such as mergers and acquisitions. In this part, the fiscal department of taxation mainly is the behavior of tax, such as the securities transaction tax in the way of IPO, company repurchase or other property tax in the segment of mergers and acquisitions, etc.

\section{Mechanism of Governmental Risk Investment Policy to Venture Investors}

Generally speaking, the fiscal department of the risk investment policy is mainly through the form of tax to adjust the investors and the high technology enterprise which uses venture capital (Heng, 2005). In this section, the author will try to apply two-period of partial equilibrium model, from income tax, to analyze how risk investment policy work on the high technology industry.

The main purpose for venture capital enters to high technology industry is to hope that with the high risk of high technology industry is equal to more generous returns. Generally speaking, the higher the risk, the more benefits. When a venture investor decided to put the fund into a high technology enterprise project, we can infer that the expected income is higher than safety investment benefits, and can be compensated for the risks of investment (Fan, 2001). So we might as well in the risk investment on the market only has a typical investor, and its behavior follows the above inference. Then the risk investor has a problem of how to distribute the fund that he owns, that is to say, how much proportion of fund to the risk investment of high technology industry, and how much to security investment. And on the analysis of that, if the government imposes taxes on risk investment process, how would the proportion change.

For simplicity, we might set as for a risk investor, his decision is depended on income $\mathrm{Y}$ and risk $\mathrm{R}$, and then we can think that for safety investment, the income and risk are 0 . Then we set the rate of income from investor's assets as discrete random variables $A_{i}(i=1,2, \ldots, n)$, and the probability of its value is $P_{i}$, then we know that the expected income meets:

$$
Y=\sum P_{i} A_{i}
$$

And meet $\sum P_{i}=1$. And the same, we can get the risk definition, that is:

$$
R=\sum P_{j} Z_{j}
$$

Among them $Z_{j}(j=1,2,3, \ldots, m)$ represents risk random variables which risk faced by investors, and there are $\sum P_{j}=1$

According to the above definition, we can in the risk - benefit diagram to describe the distribution of investment risk of investor. As shown in Figure 2, Risk investors in their investment preferences can with indifference a series of curves to represent, For example, the curve in the ${ }^{U_{1}}$ and $U_{2}$ etc. The indifference curve, Risk investment allocation in security investment (for example, to invest in government bonds) and risk investment proportion is different, But it is the same for the risk preferences of investors. We may as well assume that, when the risk faced by investors is increased, income compensation will increase the required at a higher level, that is 
to risk of investors, the risk of the marginal substitution rate is increasing income. Reflected in the risk - benefit curve, the slope of the indifference curve with gain decreasing.

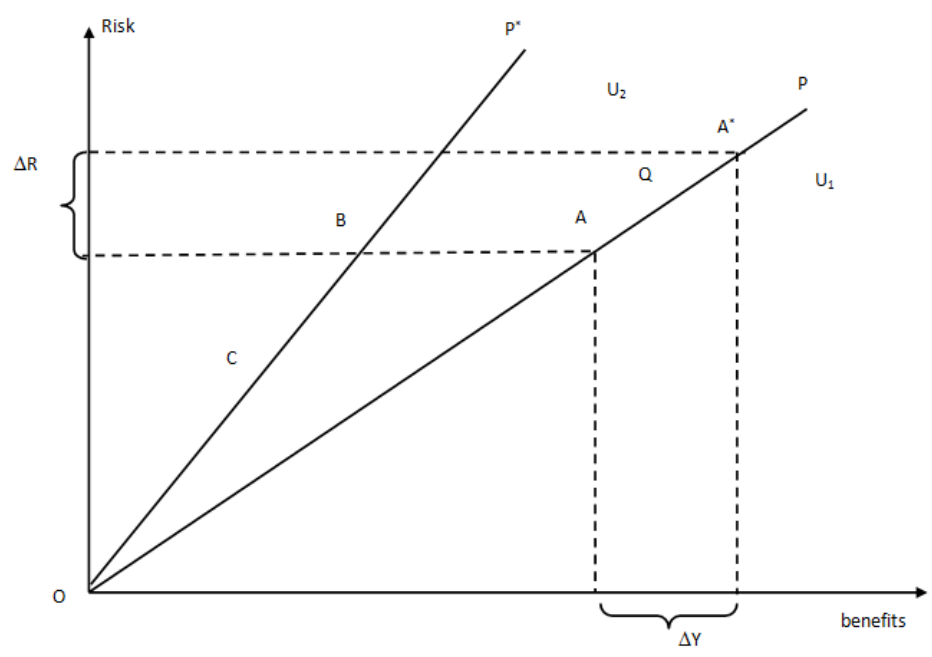

Figure 2. Mechanism of risk investment policy to venture

Investor behavior can be used in risk investment accounted for all the capital ratio, i.e. if the chance line, such as $O P$, to express the risk investor's investment strategy, then for any a point $X$ on $O P$, venture capital funds of the total capital ratio can be expressed by $O X / O P$. In the origin $O$, Venture capital accounted for 0 , All the money is invested in security investment.

When a point $X$ along the opportunity $O P$ to point $P$ line moves, can be thought of as the proportion of investment risk increases, when the point and point $P$, you can think at all of the funds has been injected into the risk investment .In the intervention of risk investment policy without the financial department of the situation, the risk investors will choose $A$ point on behalf of the investment strategy, namely $O A / O P$ is the risk funds accounted for the proportion of funds for all. To simplify the investment policy of fiscal risk and return in directly on the income tax, and the costs and benefits of having the same treatment, the income ${ }^{X_{i}} \operatorname{tax}{ }^{T X_{i}}$ for the corresponding risk investors, and if the return is negative, that is the loss in the investment, the type of the expression is the meaning of Finance for its tax refund or tax exemption.

This system is a kind of "allows full loss offset" (full loss offset) system. Of course, in reality is the case of many, such as a loss of some enterprises from other items gain reduction. Again, if the net profit is negative, then the government may according to the corresponding tax rebate or allow the loss for the next period profits after deduction and calculation of income tax.

We are not difficult to analysis that, in the above mechanism, risk investors obtain actual investment income after tax income, i.e.:

$$
Y^{\prime}=\sum P_{i} X_{i}(1-T)=Y(1-T)
$$

Similarly, the risk of investors will be reduced, that is:

$$
R^{\prime}=\sum P_{j} Z_{j}(1-T)=R(1-T)
$$

Reduce the risk and return the same proportion ${ }^{(1-T)}$, as reflected in the risk return curve, point $P$ along the chance line according to the proportion ${ }^{(1-T)}$ to the origin of mobile, and get to the point ${ }^{Q}$. For venture investors, it may also have the same interests, which may remain at the point $A$ of taking the same risks and obtain the same income. But the new chance line for $O Q$ rather than $O P$, at this time the risk of investors, changed its structure of investment. Risk investment accounted for the total capital ratio from the original $O A / O P$ increased to $O A / O Q$. That is to say, the new portfolio, risk investment decision point is located in the former opportunity line $O P A^{*}$ point, and $O A^{*} / O P=O A / O Q$. Risk investment policy of the government will "lure" risk investors more funds to risky markets (such as high technology industry market). Of course, in which the government for investors to share part of the risk $\Delta R$, and revenue from the shared risk investors investment income $\Delta Y$ 
Of course, in which the government for investors to share part of the risk, and revenue from the shared risk investors investment income. In Figure 2, the original $P$ point will move to $P^{*}$ point, and new opportunities for $O P^{*}$ line. $A$ and are $B$ located on the same horizontal line, according to the principle of similarity triangle, $A$ and $B$ said that risk investment strategy is consistent.

The biggest risk for investors utility point $C$ can be in the $B$ point above may also be under $B$, depending on the relative level of income effect and substitute effect. Risk levels will be fiscal policy to compensate for the effects of the risk investors can stand level, namely the full compensation for the loss of the case, investors will be "induced" take the risk preference of investment strategy, and if the investment policy financial risks on the compensation for the loss of 0 cases, investors are willing to take risk will be reduced. Give the government financial compensation mechanism of risk investors are not sufficient, will be less than full loss compensation mechanism level "lure" risk investors more funds into the high risk market (such as high technology industry market).

It might be further relaxed, on the assumption that the safety investment will also have the income, and the income remains positive, and whatever the income, risk investment policy of the financial sector will be on its income tax imposition. Then according to the above analysis, without taking into account the safety investment tax situation, the government tax of risk investment income will be "lure" risk investors improve risk investment ratio. And when the government imposed a safe investment income tax, if risk invariant, then the risk investors returns and there will be some reduction. Because the income elasticity of demand when the risk is bigger, so the possibility that means that the risk investors tend to reduce the risk of investment and towards greater security investment. The income elasticity of demand when the risk is small, it means that the risk investors may increase the risk of the investment ratio, and then make the risk investment has increased in size.

\section{Tax Policy for the Mechanism of the Effect of Risk Investment of High Tech Enterprises}

Generally speaking, controlling for other factors remain unchanged, the investment policy of fiscal risk for high technology companies, will mainly affect the cost of capital, thus affect the risk investment for high tech corporate investment. In fact, if the tax policy to increase high technology enterprise's cost of capital, then the risk investment will be reduced; similarly, if the tax policy to reduce the cost of capital and high technology enterprise, the venture capital investment will increase.

Effect of main tax cost of capital high technology enterprise is the enterprise income tax. Therefore, the author will focus investment effect for high technology enterprise income tax to explain. Well located in the financial sector does not levy income tax case, the cost of capital can be expressed as:

$$
C=P(r+\eta)
$$

Where $C$ represents the cost of capital, $P$ capital goods prices, said $r$ says the current market interest rate, $\eta$ rate of depreciation. When the Treasury Department to levy income tax on enterprises, the cost of capital can be expressed as:

$$
C^{\prime}=P(r+\eta)(1-t z-t x) /(1-t)
$$

Where $t$ represents the enterprise income tax rate, $z$ expressed in units of capital value of future depreciation deductions, $x$ present value represents the unit capital interest deductions. So the enterprise income tax for the role of investment depends on the size of $(1-t)$ and $(1-t z-t x)$. The current greater than the latter, we can think the enterprise income tax reduced investment. And correspondingly, if the latter about the former things, then we think the enterprise income tax reduces the cost of capital, thereby stimulating investment. If capital depreciation and interest deduction value meet the $Z+X=1$, is that corporate income tax has no effect on the cost of capital and capital pull. If you allow capital in accordance with the ratio of $\eta$ depreciation also allows the interest deduction, so that the net present value per unit of capital depreciation and interest deduction value can be expressed as:

$$
\begin{gathered}
z=\sum(1+r)^{-n} \eta(1+\eta)^{-n}=\eta /(r+\eta) \\
x=\sum(1+r)^{-n} r(1+\mu)^{-n}=r /(r+\eta)
\end{gathered}
$$

It is not difficult to have $z+x=1$, the cost of capital for $P(r+\eta)$. It is not difficult to see from the type (6), when the current taxation policy allows the most interest deductions, depreciation rate will be the key elements of 
capital cost. Might as well let taxation policy stipulated depreciation rate of $\delta$ is less than the actual depreciation rate $\eta$ then depreciation unit capital deduction value:

$$
z^{\prime}=\sum(1+r)^{-n} \delta(1+\delta)^{-n}=\delta /(r+\delta)
$$

The present value of a unit of capital and the interest deduction, so it is not difficult to know, the cost of capital:

$$
C=P(r+\eta)+[\operatorname{Ptr}(\eta-\delta) /(1-t)(r+\delta)]
$$

It is not difficult to see from equation (10), if $\eta>\delta$, Depreciation, provisions of fiscal and tax policy rate is lower than the actual depreciation rate, so the cost of capital will increase, risk investment will be inhibited; In contrast, if fiscal policy implementation of accelerated depreciation of the system, then the capital costs will be reduced, the risk investment activities will be active.

\section{Conclusions}

The investment policy of fiscal risk mainly through tax in the form of the venture capital investors and the use of high tech enterprises of venture capital are adjusted. The two period the partial equilibrium model on high tech industry financial support policy of investment risk mechanism was analyzed by using the obtained, tax, tax and the tax base of different will affect the risk investors will to a large extent and the cost of capital high technology enterprise use of venture capital, then influence the development of high tech industry the pace of. The risk of investors, the income elasticity of demand for government changes to tax risk investment income will change the risk, thus affecting the willingness of investment and the proportion of investment risk to investors(Liu et al., 2007). The use of venture capital enterprises, tax policy changes, such as the calculation method of pre tax deduction of enterprise income tax changes, will affect the capital cost to a certain extent, affect the active degree of risk investment.

\section{References}

Chen, D. M., Pei, X. S., \& Shen, M. H. (1998). High technology investment risk prediction and assessment theory and method. Forecast, 17(1) 48-52.

Fan, W.-Y. (2001). The research on venture capital market. Jinan University

Guo, Q.-W., \& Luo, N. (2001). The Theory and Research on the Relationship of the Taxation and Venture Capital. Public Research, (7), 18-25.

He, W. (2005). Venture Capital Investment and Technological Innovation of High-tech Enterprises. Wuhan University.

Huang, H.-L. (2009). Study of tax Policy on venture capital in China. Southwestern university of finance and economics.

Liu, Z.-W., Wang, D.-P., \& Liu, C. (2007). The governmental public subsidies for risk investment. Journal of management, 1(11), 833-838

Luo, L.-P. (2010). A study of improving the fiscal and taxation Policy of china's venture capital. Northeast university of finance and economics.

$\mathrm{Su}, \mathrm{D} .-\mathrm{Y}$. (2007). The fiscal policy research on high technology industry investment and financing system in China. Social science issue, 2(6), 137-140.

Tao, Y.-Y., \& Xiong, P. (2004). High and new technology enterprise technology innovation and venture capital research. Industrial technology economy, 23(4), 70-74.

Yuan, X.-L. (2004). Tax policy choices to promote the development of risk investment. Studies of finance and economics, 3(5), 11.

Zhang, Q.-S. (2009). Jin-cheng Zhang.Analysis on High technology enterprise risk investment fiscal policy. Scientific management research, 2, 26.

\section{Copyrights}

Copyright for this article is retained by the author(s), with first publication rights granted to the journal.

This is an open-access article distributed under the terms and conditions of the Creative Commons Attribution license (http://creativecommons.org/licenses/by/3.0/). 